State Higher Education Spending and the Tax Revolt

Robert B. Archibald

College of William and Mary

David H. Feldman

College of William and Mary

College of William and Mary

Department of Economics

Working Paper Number 10

November 2004 
COLLEGE OF WILLIAM AND MARY

DEPARTMENT OF ECONOMICS

WORKING PAPER \# 10

November 2004

\title{
State Higher Education Spending and the Tax Revolt
}

\begin{abstract}
State policies resulting from the tax revolt of the late 1970s play an important role in determining the timing and magnitude of the decline in state tax effort for higher education. An understanding of the fiscal environment caused by these provisions is critical for the future of state-supported higher education.
\end{abstract}

JEL Classification: I22, H71

Keywords: State higher education spending, Tax revolt, Tax and expenditure limits

Robert B. Archibald

Department of Economics

College of William and Mary

P.O. Box 8795

Williamsburg, VA 23187-8795

rbarch@wm.edu
David H. Feldman

Department of Economics

College of William and Mary

P.O. Box 8795

Williamsburg, VA 23187-8795

dhfeld@wm.edu 


\section{State Higher Education Spending and the Tax Revolt}

\section{Introduction}

Government subsidization of public higher education primarily is a function of the states. Even today, with budgets in crisis, the states provide over four dollars of support for higher education expenses for every dollar of federal subsidy. Yet public effort in support of higher education - measured as state funding per $\$ 1000$ of personal income - has been in decline for the last quarter century. The magnitude of this decline has been quite significant. Aggregate state effort has fallen by thirty percent since the late 1970s.

In this paper we evaluate the connection between state higher education effort and the tax revolt that began in the 1970s. The tax revolt gave birth to a set of laws and constitutional provisions that have dramatically changed taxing and spending policies in many states. The tax revolt is based on the notion that government is too large, and that the appropriate strategy is to "starve the beast." The most prominent legal change resulting from the tax revolt is the Tax and Expenditure Limitation (TEL), which limits the growth of state revenue or expenditures to some outside indicator, most commonly the growth of state personal income. Starting in the late 1970's twenty-three states adopted a TEL. Also, though this happened more slowly and less often, states added super majority requirements (SMRs), typically two-thirds, for the legislature to approve tax increases. Thirteen states have an SMR.

We use a forty-one year panel of state data from 1961 to 2001 to investigate the importance of these tax revolt institutions for state effort on higher education. Both TELs and SMRs prove to be very robust predictors of the time series and cross sectional 
variation in state funding effort. Together with rising costs, this retreat of public effort is a major component of the financial difficulties faced by state-supported colleges and universities. One measure of the consequences of this financial crisis at public institutions is the ratio of spending per full time student at public institutions relative to private institutions. In 1980 public institutions spent seventy cents for every dollar spent at private colleges and universities. By the late 1990s that figure had fallen to fifty-five cents. ${ }^{1}$ Understanding the causes of this retreat is crucial if there is any chance of reversing it. Changing the political climate is never easy, but our results suggest that the task ahead is even more difficult. All of the SMRs and a majority of the TELs are amendments to state constitutions. They are firmly in place.

The questions that motivate our paper arise at three distinct levels of generality. At the highest level, the issue is whether or not institutions actually affect policy outcomes. At the next, more specific level, the question is whether or not the particular institutions spawned by the tax revolt affect policy. There is an extensive literature, both theoretical and empirical, on these two questions. Our contribution comes from extending the discussion to the third and most specific question; have the tax revolt institutions had a meaningful effect on higher education effort in particular. In this introduction we briefly review the literature on the highest level question. We discuss the more specific implications of the tax revolt institutions in separate sections of the paper.

That political institutions should matter for policy outcomes is not self-evident. In much of the political economy literature as it has evolved since Anthony Downs (1957), policy outcomes are driven by the preferences of the median voter. This is true if

\footnotetext{
${ }^{1}$ See Thomas Kane, Peter Orszag and David Gunter (2003).
} 
politicians know voter preferences and can align their proposals accordingly. In this case there is little scope for the institutional structure of decision making to exert an independent effect on policy outcomes. Institutions become important again whenever any of the assumptions of the Downsian paradigm are removed.

In particular, political parties may care about policy as well as winning elections. They may have imperfect information about voter preferences, and those preferences may not be single peaked. ${ }^{2}$ They may be dependent on political contributions that come from the extremes within a polarized electorate. An independent role for interest groups also calls into question the spatial choice nature of median voter models. ${ }^{3}$ Lastly, in multiissue political settings, the theoretical work of Kenneth Shepsle and Barry Weingast (1981) and Thomas Romer and Howard Rosenthal (1978) show the importance of restrictions on the power to propose policies within a legislative process. These changes to the basic assumptions all may lead to departures from the median voter's preferred outcome or to the reduced political salience of the median voter, creating a role for institutions to affect policy choices.

Timothy Besley and Anne Case (2003) provide a thorough review of the theoretical and empirical literature on the role political institutions play in determining policy choices in the United States. They consider electoral rules such as limitations on who can vote and whether or not proportional representation is used and decision making rules such as the line item veto, rules for appointing regulators, and whether agencies are independent or not. They conclude their detailed review of this literature by saying that the evidence from the US clearly indicates that institutions do matter. Specifically,

\footnotetext{
${ }^{2}$ See Alberto Alesina (1988).

${ }^{3}$ This is the basis for work by Matsusaka (1995) and Gilligan and Matsusaka (1995) on the role of the popular initiative and of logrolling as determinants of state spending.
} 
"There can be little doubt that the structure of political representation, the terms on which elections are fought, and the rules governing the policy process, all influence policy outcomes." 4

We address the remaining questions in six additional sections. In section II we explain the institutions of particular interest to us, TELs and SMRs, and review the literature about their effects on state budgets. In the third section we review the evidence of the slowdown in higher education spending and the literature on this slowdown. In the fourth section, we describe the model and the data we use to test our hypothesis that the tax revolt institutions have an important impact on state spending effort for higher education. The fifth section presents our results. We discuss the policy implications of our finding in section VI. The final section contains conclusions.

\section{Tax Revolt Institutions and Research on the Tax Revolt}

Tax Revolt Institutions - Individuals who did not trust legislatures started the tax revolt. They were deeply concerned with the growth of government at all levels, but particularly with the growth of state government. The basic strategy of the tax revolt is to put hard limitations on the growth of state tax revenues, or direct limits on spending growth. Given balanced budget requirements the approaches are very similar.

There are a number of theoretical reasons to expect that marginal voters might respond favorably to proposals that reduce the flow of resources toward public sector uses chosen by a legislature. ${ }^{5}$ Agency problems in politics may be similar to those that characterize corporate governance. If constituents have limited information about their

\footnotetext{
${ }^{4}$ Besley and Case (2003), page 67.

${ }^{5}$ See John Matsusaka (1995).
} 
representatives, legislators may shirk and implement policies contrary to constituent interests without being punished at the polls. And logrolling within legislatures may help win approval for projects that are highly valued by some representatives even if they do not command a public majority. This provides a rationale for why initiatives make their way onto the ballot - citizens distrust elected officials.

Many of the TELs, however, were results of the legislative process itself. There is ample support in the literature for why legislatures might act this way. ${ }^{6}$ TELs and SMRs throw sand in the gears of government, thus constraining future legislatures that may have a different attitude toward the fiscal role of government. Starting in 1976, twenty-three states enacted TELs. Sixteen of the twenty-three TELs were enacted in the four-year period from 1977 to 1980 . A super majority requirement for a tax increase is motivated by the same fear of the growth of government. If we make raising taxes more difficult, it will be harder for government to grow. SMRs are much less prevalent than TELs, and in most cases they are a much more recent phenomenon. Only thirteen states have such requirements, and six of these enacted their SMR in 1992 or thereafter.

Table 1 gives a listing of the states that have TELs and some of the characteristics of the provisions. These TELs are all limitations on total state spending or total state revenues as opposed to similar restrictions that affect particular taxes, typically property taxes. The TELs are a hodgepodge of different types of regulations. Some are constitutional provisions, and others are statutory. Some TELs restrict expenditures and others restrict taxation. Most limitations are based on the growth of personal income in the state, but some states use population growth and inflation. Also, the exact

\footnotetext{
${ }^{6}$ Guido Tabellini and Albert Alesina (1990) show how strategic choices made by a current majority can constrain future majorities that may disagree with them using tools (like budget deficits) that may not be socially optimal.
} 
composition of the budget subject to the restriction varies across states. In our empirical work below we will focus on three distinctions among TELS.

The first of these distinctions was suggested by Besley and Case (2003), who distinguish between TELs that impose restrictive limits and ones that impose nonrestrictive limits. Non-restrictive limits are ones that are either binding on the administration's budget submissions, but not on the budget the legislature eventually passes, or that require only a simple majority of the legislature to override. A priori one would expect restrictive TELs to have a greater effect on the decisions of budget makers than non-restrictive ones.

Our second distinction concerns the breadth of the TEL. Breadth is a difficult thing to measure, but it clearly varies across states. For the purposes of our analysis, we determined whether or not college tuition, or expenditures funded by tuition, was affected by the TEL. In cases in which tuition revenue is considered part of the budget that is limited by the TEL, the states generally had very broad-based limitations. For example, Article IX, Section 17 of the Arizona constitution, which outlines the TEL, includes, ${ }^{7}$

(2) For the purposes of this article, "state revenues":

(a) Include all monies, revenues, fees, fines, penalties, funds, tuitions, property and receipts on any kind whatsoever received by or for the accounts of the state or any of its agencies, departments, offices, boards, commissions, authorities, councils and institutions except as provided in this subsection.

This describes a very broad-broad based TEL, much broader than in some states which explicitly exclude tuitions, fees, and other charges from the revenue subject to the limit. There are six states in our sample that include tuition, or expenditures funded by tuition, under their TEL.

\footnotetext{
${ }^{7}$ Information on all of the tax revolt provisions including the languages in the statutes and constitutional amendments is available at www.limitedgovernment.org (accessed March 31, 2004).
} 
The difference between a fixed-based TEL and a moving-based TEL is the final distinction of interest. A fixed-base TEL is one in which a state sets a limit and augments the limit each year. Article XIII B of the California constitution provides an example of a fixed-base TEL,

SPEC 1. The total annual appropriations subject to limitation of the State and of each local government shall not exceed the appropriations limit of the entity of government for the prior year adjusted for the change in the cost of living and the change in population, except as otherwise provided in this article.

We term this a fixed-base TEL because the limit is established on a base from the year in which the limitation started (1979) and the limit is augmented by a formula. The important point is that the limit is not affected by last year's spending.

Article XXVIII of the Connecticut constitution provides an example of the alternative, a moving-based TEL:

Sec. $18 \mathrm{~b}$. The general assembly shall not authorize an increase in general budget expenditures for any fiscal year above the amount of general budget expenditures authorized for the previous fiscal year by a percentage which exceeds the greater of the percentage increase in personal income or the percentage increase in inflation, ...

This is a moving-base TEL because in each year the base for the limit is the previous fiscal year's expenditures. The important distinction is between a limit on total spending - a fixed-base TEL - and a limit on each year's additional spending - a moving-base TEL. If the intent of the tax revolt was to limit the growth of state spending, the moving-base TEL should be more effective. Our discussions with state budget officers in several states with fixed-based TELs suggested that the TEL, though present, did not constrain the budget process because a large gap had grown between the limit and actual state spending. Such a gap is not possible with a moving-based TEL. Eight states have 
fixed-based TELs; fourteen states have moving-based TELs, and one state, Utah, computes its TEL using a formula that is a mix of the two methods.

SMRs, on the other hand, are much more uniform, and all are parts of the state constitutions. Table 2 lists the states with SMRs and gives the dates adopted and the percentage needed to increase taxes. Some of the SMRs are provisions for temporary or emergency tax increases that later have to be approved by a vote of the citizenry, but most of them are explicit constraints on the state legislature. Nine of the thirteen states that have an SMR also have a TEL, but it is only seldom the case that they were adopted in the same year. Typically a state adopted its SMR after it had adopted a TEL.

Tax Revolt Research - The literature on the tax revolt focuses on whether or not it has achieved its main objective. Therefore studies look at the effects of tax revolt limitations on aggregate state budgets. Existing studies do not universally find a significant effect of TELs on aggregate state expenditures or aggregate state revenues. It has been easier to find significant effects for SMRs. The studies on TELs fall into two camps. The first camp includes Burton Abrams and William Dougan (1986), Ronald Shadbegian (1996), and Dale Bails and Margie A. Tieslau (2000), who find that a TEL significantly decreases the size of state government, though Shadbegian's result only holds when the TEL indicator variable is interacted with state income. Studies in the other camp include Kim Rueben (1997), who finds no effect of a TEL using OLS or fixed effects models, and Brian Knight (2000) who finds that SMRs have a significant effect but that a TEL does not. Besley and Case (2003) also conclude that TELs do not shrink state budgets, but that SMRs do have a significant effect. ${ }^{8}$

\footnotetext{
${ }^{8}$ Some of their results actually suggest perverse effects of TELs.
} 
Much of the difficulty in this literature stems from the fact that the introduction of a tax or expenditure limit or a super majority rule is endogenous to the process of determining the size of state government budgets. Typically these measures are introduced when a significant proportion of the state's legislators, or the state's voters in states that have the initiative process, become convinced that state spending or taxing is "out of control." Rueben (1997), and Knight (2000), deal with this problem by creating an instrument for the TEL or SMR. The estimates using the instrument find effects for either TELs (Reuben) or SMRs (Knight) that are much larger and are more precisely measured than their other results suggest. By focusing on a state's spending within a subset of its budget we avoid the problem of whether or not a TEL or SMR is endogenous. There exists no theory and/or evidence to suggest that increases in higher education spending alone were the trigger for the initiation of a TEL or an SMR.

\section{The Slowdown in State Appropriations for Higher Education}

Students of higher education finance are indebted to the Grapevine project at Illinois State University for carefully collecting data on state appropriations for higher education. Figure 1 displays these data for all states. ${ }^{9}$ The data are for state higher education tax effort, measured as appropriations per $\$ 1,000$ of state personal income. State tax effort measures the willingness of state taxpayers to pay taxes and appropriate the proceeds to run the state-supported colleges and universities. The figure shows two distinct trends. Citizens' willingness to support higher education grew from 1961 to the late 1970 s and decreased thereafter.

Figure 1. State Appropriations for Higher Education for $\$ 1000$ of Personal Income, Fiscal Years 1961 - 2004

\footnotetext{
${ }^{9}$ These data can be accessed at www.coe.ilstu.edu/grapevine/ (accessed June 11, 2004).
} 


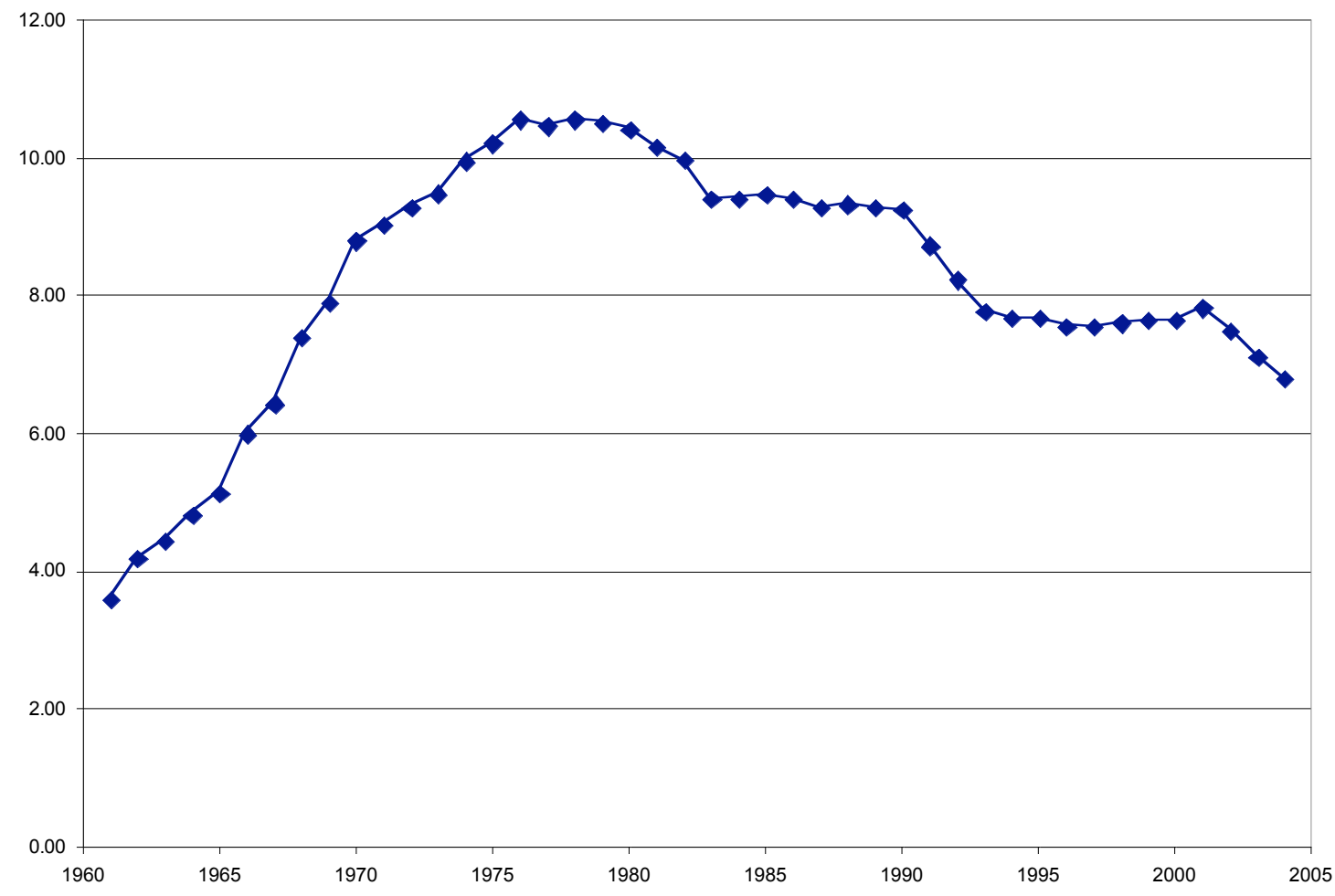

The basic pattern described by Figure 1 is repeated in each state. In every case the data exhibit a hump-shaped pattern. Table 3 shows the years of peak effort for each state. Effort in twenty-nine states peaked between 1974 and 1980, which is consistent with the peak in aggregate data in Figure 1. There are, however, clearly some outliers. Effort peaked in South Dakota in 1969 and did not peak in Massachusetts, Ohio, Wyoming, and Iowa until 1988 or thereafter.

Table 4 gives more detail on effort by state by displaying the data in rank order for 1961, 1970, 1980, 1990, and 2000. While picking patterns out of such a busy table is not easy, there are some noteworthy findings. Some states seem to have very consistent patterns. Massachusetts displays consistently low effort, ranking either first, second, or third in all five years. Michigan is usually in the middle; its rank varies from sixteenth to twenty-ninth. North Dakota is usually very high; it ranks above forty-five for every year but 1980 in which it is thirty-first. There are also states that clearly moved around in the 
rankings. Vermont started out above average at twenty-sixth in 1961 and improved to thirtieth in 1970, but its ranking fell precipitously thereafter, to eighth in 1980, third in 1990 , and second in 2000. There is a similar story for Colorado. It started well above average at thirty-fourth in 1961, but declined to the tenth ranked state in 2000 . New York, by contrast rode a roller coaster that ended roughly where it began, among the lowest effort states. Yet in the middle year (1980), New York had risen to sixteenth.

The fact that these state-level data share a basic pattern suggests that the declines in state appropriations have common causes. On the other hand, the variation among states means there also must be influential state-specific factors. In our analysis below, we attempt to determine the effect of both types of factors.

Previous Literature - There have been a great number of books and articles written about increases in college tuition. ${ }^{10}$ There is also an extensive literature on the relationship between tuition at state-supported colleges and universities, state financial aid spending, and state appropriations. ${ }^{11}$ But to the best of our knowledge there are no studies that try to measure the effects of tax revolt provisions on higher education spending.

Don Hossler, Jon P. Lund, Jackie Ramin, Sarah Westfall, and Steve Irish (1997), provide a good example of a typical discussion of the fall in state appropriations for higher education. They argue that the most significant trends affecting state appropriations include:

“...competing demands for state-funds, declining federal commitment to student financial aid, sluggish state economies, declines in disposable family income, and increased demand for postsecondary education. (Page 161)."

\footnotetext{
${ }^{10}$ Two excellent books on tuition are: Arthur M. Hauptman (1990) and Ronald G. Ehrenberg (2000).

${ }^{11}$ See, for example, Hearn, Griswold, and Marine (1996), Griswold and Marine (1996), and Robert C. Lowry (2001).
} 
Since the effort variable we use controls for state personal income, declines in disposable family income are not part of the explanation in our case. Of the other issues, Hossler et al focus on the effects of falling appropriations on tuition and financial aid spending. This is an important topic, but it not our interest in this paper.

Rajindar K Koshal and Manjulinka Koshal (2000) estimate a model of state appropriations using a single cross section of states in 1990. They build a two-equation structure with one equation for tuition at state supported institutions and one equation for state appropriations for higher education. They posit correctly that the causation between tuition and state appropriations is two-way. While they confirm the two-way causation which is their focus, their model does not provide us much guidance. In particular, per capita state revenue is an important explanatory variable in their equation for state appropriations. In our study we do not want to hold tax revenues constant. The tax revolt limitations may well affect appropriations to higher education by affecting tax revenues. To capture this, we have to allow tax revenues to vary.

Thomas Kane, Peter R. Orszag, and David Gunter (2003) also estimate a model of state appropriations for higher education. They use panel data for 48 states from 19772001, though data availability does not allow them to use all years in some cases. They hypothesize that other spending priorities, specifically spending on Medicaid and Corrections, have crowded higher education spending out of the budget. They provide evidence for this hypothesis the case of Medicaid, but fail to find any support in the case of Corrections. Also, like Koshal and Koshal, Kane, Orszag and Gunter include total state revenue as an explanatory variable. 
In microeconomics terms, using state revenue as an explanatory variable allows these authors to determine the extent to which higher education spending, the corrections budget, and health spending are net substitutes within a given state budget (i.e. holding the budget constant). Within a budget of a given size if spending on Medicaid is rising due to federal mandates or incentives, some other components of the budget must fall. Kane, Orszag and Gunter have demonstrated that higher education spending is one such component. But if the budget itself is endogenous, these expenditure categories may be gross complements instead. In other words if revenues rise (fall) by five percent, spending on higher education and on Medicaid may both increase (decrease). Their results therefore capture the effect of limited revenues on higher education appropriations when there are pressures to increase spending on other budget items. But they are silent about the determinants of these revenues, which is part of our story.

Koshal and Koshal (2000) and Kane, Orszag, and Gunter (2003) both use data that start after the slowdown shown in Figure 1. Our aim is to explain the whole picture, both the increases in funding in the 1960s and early 1970s and the decreases in funding in the late 1970s and the 1980s and 1990s. Our data will start with fiscal year 1961. This is important because with data starting in the early 1960s our identification of an effect of the tax revolt institutions will be based not only on cross-section variation among states with and without these provisions but also on time series variation within the states that adopted the provisions during our sample period.

\section{Empirical Model}


To evaluate the relationship between state higher education effort and the institutional variables that capture the tax revolt's impact we estimate an empirical model that takes the following form:

$$
E_{i t}=\boldsymbol{E}\left(T E L_{i t}, S M R_{i t}, \boldsymbol{P}_{i t}, \boldsymbol{S S _ { i t } ,} \boldsymbol{D}_{i t,}, \boldsymbol{S} \boldsymbol{t}_{i}, \boldsymbol{Y} \boldsymbol{r}_{t}\right) .
$$

The dependent variable is state appropriation effort for higher education. The subscript $i$ codes for the state and the subscript $t$ refers to year. The two institutional variables are tax and expenditure limits (TEL) and supermajority requirements (SMR). If the institutional constraints have an impact on effort, our statistical model should pick up this independent effect in the coefficients on TELS and SMRs. The variables $\boldsymbol{P}_{i t} \boldsymbol{S} \boldsymbol{S}_{\boldsymbol{i t}}$, and, $\boldsymbol{D}_{i t}$, are vectors, respectively, of state-level political variables, other state spending, and demographic controls. These variables are discussed in detail below.

Because we are pooling cross-section and time series data we include state $\left(\boldsymbol{S t _ { i }}\right)$ and year $\left(\boldsymbol{Y} \boldsymbol{r}_{t}\right)$ fixed effects in addition to the other controls. State fixed effects control for long lasting but unobservable differences between the states that influence higher education effort, while the time fixed effect controls for unobservable year effects that are common across the states. Fixed effects models of this sort have advantages and disadvantages. Adding dummy variables for each state and for every year consumes degrees of freedom, and since the coefficients on these dummy variables are capturing the effects of many unobserved influences we must be careful not to attribute specific meaning to their sign and magnitude. On the other hand, alternatives to fixed effects models, such as error-components models, make explicit assumptions about the structure 
of the error term that we cannot justify. Since we have a large data set, the fixed effects model (using ordinary least squares) is the appropriate estimation technique.

Dependent Variable - The dependent variable for our analysis is state appropriations per $\$ 1000$ of personal income. State appropriations for higher education are tax fund appropriations for the current operations of state institutions of higher education, for state coordinating boards, and for state scholarship programs. They explicitly exclude appropriations for capital outlay, appropriations of resources derived from other sources, e.g. Federal sources or tuition, and they do not include funds derived from lotteries. These data are collected by the Grapevine project at the Illinois State University. State personal income is estimated by the Bureau of Economic Analysis of the Department of Commerce. ${ }^{12}$

Tax Revolt Variables - We use indicator variables for the presence of TELs and SMRs. Also, as we explain below, we separate our TEL variable according to various properties of the TEL.

Variables for Other State Spending - State expenditures on higher education may be related to state needs in other areas, particularly spending on health care and on corrections. We use data from the Bureau of the Census on state government finances for Total Direct Expenditures on Corrections and Total Direct Expenditures for Health and Hospitals to capture these effects. We express theses variables as expenditures per $\$ 1,000$ of state personal income.

Since expenditures on health and hospitals and expenditures on corrections are determined by the same political process as are expenditures on higher education, we test

\footnotetext{
${ }^{12}$ By choosing this dependent variable we are implicitly assuming that the income elasticity of higher education appropriations is one, i.e., that the correct function is:

Higher Education Appropriations $=\boldsymbol{E}\left(T E L_{i t}, S M R_{i t}, \boldsymbol{D}_{i t}, \boldsymbol{S S _ { i t }}, \boldsymbol{P}_{\boldsymbol{i t}}, \boldsymbol{S t _ { i }}, \boldsymbol{Y \boldsymbol { r } _ { \boldsymbol { t } }}\right) \cdot$ Personal Income.
} 
whether these variables can be used as exogenous variables in a regression determining higher education effort. To determine if we should use an instrumental variables procedure instead of OLS for our estimates, we performed a Hausman test. ${ }^{13}$ We used state-level statistics on the rate of major crimes and on the crude death rate as instruments. ${ }^{14}$ The Hausman test indicated that there is not a systematic difference between the instrumental variables and ordinary least squares regression coefficients. ${ }^{15}$ We also performed a Bound, Jaeger and Baker (1995) test for weak instruments. In this case we could reject the hypothesis of weak instruments. ${ }^{16}$ These test results give us confidence that the ordinary least squares results we present are not tainted by simultaneous equations bias.

Control Variables for State Politics - Our equations need to control for state ideology and party affiliation of elected officials. We will use seven variables. The first variable is a measure of state citizen ideology from the work of William D. Berry, Evan J. Ringquist, Richard C. Fording, and Russell L. Hanson (1998). ${ }^{17}$ This variable combines ratings for the ideology of the state's Congressional delegation from the Americans for Democratic Action and the AFL/CIO's Committee on Political Education. This rating is designed so that the maximum score of one hundred is given to an extreme liberal, and the minimum score of zero is given to an extreme conservative. The ratings for the

\footnotetext{
${ }^{13}$ See Pindyck and Rubinfeld (1991).

${ }^{14}$ The rate of major crime comes from the Uniform Crime Reports published by the Department of Justice, and the death rate comes from Vital Statistics of the United States published by the Department of Health and Human Services.

${ }^{15}$ The null hypothesis for the Hausman test is that the coefficients from OLS and Instrumental Variable regression are not systematically different. In our case the test statistic of 18.85 , which is distributed ChiSquared with 99 degrees of freedom, is clearly in the fail to reject region.

${ }^{16}$ The null hypothesis for the Bound, Jaeger, and Baker test is that the instruments are weak. For Health and Hospitals the test statistic, which is distributed F with 2 and 1805 degrees of freedom, was 4.85, clearly in the reject region. For Corrections, the test statistic, which has the same distribution, was 10.45, yielding another rejection.

${ }^{17}$ This measure has been updated through 2002. These data can be found at www.icpsr.umich.edu:8080/ICPSR-STUDY/01208.xml (accessed June 11, 2004).
} 
members of the state's Congressional delegation are averaged to get the rating for the state's citizens.

For party affiliation we included three indicator variables each of which is equal to one if the Democratic Party controls, respectively, the governorship, a majority of the lower house in the legislature, or a majority of the upper house in the legislature, and zero otherwise. To capture potential shifts in the ideological content of party affiliation, we also interacted each of these variables with an indicator variable equal to one in 1980 and thereafter. We chose 1980 as the break because of the profound effect of the Reagan presidency and the political transformation of the south. As Alexander Lamis (1984) demonstrates, the number of state-wide elected officials (Governors and Senators) from the Republican Party in the south increased dramatically in 1980. Also, the work of Earl Black and Merle Black (2002) suggests that the rise of southern republicans that started in 1980 caused southern democrats to shift ideological positions. They argue that in many cases Democratic Party elites were outflanked on the right by the new Republicans, so the party leadership became more moderate. ${ }^{18}$

Other Control Variables - All of our regressions have a full set of indicator variables for state and year effects. ${ }^{19}$ In addition, to control for the possibility of scale effects that might vary by state size and differences in the age structure of states we include the four variables Besley and Case (2003) use as controls in their regressions. These are the percentage of the state population in the 5 to 17 age group, the percentage of

\footnotetext{
${ }^{18}$ We recognize the ad hoc nature of this procedure. While the evidence in Lamis (1984) suggests that 1980 is a likely candidate for a break, we cannot be sure it is the best break point. In our defense, this is the only break we investigated. It is not the result of a data mining exercise.

${ }^{19}$ The presence of indicator variables for the states precludes using similar variables for regions, which are often found in analyses of state higher education policy. There are very likely to be regional differences in higher education policies, but including regional variables rather than state variables forces each state in a region to have the same coefficient and leads to a poorer fitting model. We provide an analysis of regional differences below.
} 
the state population over age 65 , the state population, and the state population squared.

Lastly, we have included the percentage of the state population in the prime college going age group, 18-24 year olds. ${ }^{20}$

Following Besley and Case (2003) as well as Kane Orzag and Gunter (2003), we started with a panel data set of the forty-eight continental states from 1960 through 2000 . Including variables for party affiliation in the upper and lower houses of the state legislature required us to eliminate Nebraska because of its unicameral legislature. Also, the state of Minnesota did not have partisan elections for the state legislature prior to 1973, so there is no information on the party affiliation of legislators in Minnesota for 1960 through 1972. Because of these considerations we have a data set with 1914 observations; 46 states for 41 years and one state for 28 years. ${ }^{21}$ Table 5 gives the means, standard deviations and sources for the variables we used in the regressions reported below.

\section{Results}

Table 6 contains our results. ${ }^{22}$ Equation 1 uses the simplest measures of the tax revolt variables, indicator variables for the presence of a TEL and the presence of an SMR. Both variables have statistically significant coefficients of the expected sign. The two tax revolt provisions reduce higher education taxpayer effort. Together they can explain over half of the observed decline in effort over the period.

\footnotetext{
${ }^{20}$ The Bureau of the Census did not publish annual estimates of state population that included the 18-24 year old population for the 1960s. Our data for the 1960s were our own estimates based on data for population by individual ages from the 1960 census. We then aged these population figures with an allowance for migration and mortality. Details of these estimates are available on request from the authors.

${ }^{21}$ For comparability with Besley and Case (2003) and Kane, Orzag and Gunter (2003), we did produce results for all 48 states by eliminating the legislative variables. These results were very similar to the results we present below.

${ }^{22}$ The full results, including all the control variables and the state and time indicator variables are available on request from the authors.
} 
The two variables for other state spending have positive signs, which indicates that spending on corrections and on health and hospitals are complements to higher education spending. As we noted earlier, results suggesting that other state spending crowds out higher education come from regressions that control for total state spending, i.e., they demonstrate that, for a given level of state spending, more spending on corrections and/or health and hospitals will lead to less spending on higher education. Our regressions do not control for total state spending. They indicate that where and when there is more spending for corrections, and particularly for health and hospitals, there is also more spending for higher education. This result likely reflects differences in tastes for public goods that overpower any effect from budget tradeoffs. The results for Corrections and Health and Hospitals are very consistent across the various specifications of the TEL variable in the remainder of the table.

The control for state ideology also has a statistically significant coefficient. More liberal states have higher state appropriation effort for higher education. The coefficient on this variable is very stable across the various specifications of the TEL variable in the remainder of the table. The two variables measuring the effect of a democratic governor suggest that prior to 1980 , states with democratic governors had lower state appropriations for higher education, but in 1980 and thereafter, when the effect of a Democratic governor is measured by the sum of the two coefficients, the sign of the coefficient for Democratic Governor changes. The sum of the two coefficients is not statistically significant in the first two specifications, but it is in the second two. ${ }^{23}$ The coefficients on the variables for the party affiliation of the legislature also show that the

\footnotetext{
${ }^{23}$ The F statistic for the test that the sum of the two coefficients 1 and 1809 degrees of freedom. It is 2.00, $2.59,8.71$ and 12.69 for columns $1,2,3$, and 4 respectively. The first two are not statistically significant, but the last two are.
} 
break in 1980 is important. The results for the lower house mirror those for the party affiliation of the governor. Prior to 1980, having a majority of the lower house from the Democratic Party had a detrimental effect on state spending on higher education. In 1980 and thereafter, when the effect of a Democratic majority is found by summing the two coefficients, the effect changes sign. In this case, the sum of the two coefficients is not statistically significant in any of the specifications. ${ }^{24}$ The results for the upper house are different. In this case, both before and after 1980, a democratic majority is associated with increased higher education funding, but the effect after 1980 is much diminished. In fact, in 1980 and thereafter, when the effect is measured by the sum of the coefficients, none of the summed coefficients are statistically significant. ${ }^{25}$

Equation (2) investigates the distinction between restrictive TELs and nonrestrictive TELs suggested in Besley and Case. The coefficients on the two indicator variables have the same sign and roughly the same magnitude. This distinction does not appear to be meaningful for the effect of a TEL on taxpayer effort to support higher education. ${ }^{26}$ We interpret this to mean that the presence of an explicit limit, even one that is only advisory or easy to circumvent, has a dampening effect on higher education effort. In the results that follow, we will not continue to use this distinction.

Equation (3) distinguishes between broad-based TELs that include tuition, and narrow-based TELs that do not. The result here is striking. The coefficient on TELs that

\footnotetext{
${ }^{24}$ The F statistic for the test that the sum of the two coefficients 1 and 1809 degrees of freedom. It is 2.29 , $3.78,1.06$, and 1.16 for columns $1,2,3$, and 4 respectively. None of these F statistics are large enough to allow us to reject the hypothesis that the sum of the coefficients is zero.

${ }^{25}$ The $\mathrm{F}$ statistic for the test that the sum of the two coefficients 1 and 1809 degrees of freedom. It is 1.00 , $1.17,0.25$, and 0.11 for columns $1,2,3$, and 4 respectively. None of these F statistics are large enough to allow us to reject the hypothesis that the sum of the coefficients is zero.

${ }^{26}$ The test statistic for the difference between these two coefficients is distributed F with 1 and 1810 degrees of freedom. This test statistic is 1.18 , which is not sufficiently large to reject the hypothesis that his difference is zero, i.e., the two coefficients have the same value.
} 
include tuition is very large and highly statistically significant while the coefficient on TELs that do not include tuition is much smaller, though still statistically significant. This suggests that very broad-based TELs create much stronger downward pressure on spending because there is little leeway for legislatures or governors to find unrestricted funding sources for activities. In these states, the TEL has considerably more bite than in other states. The coefficient for SMR is still statistically significant, though its magnitude is diminished compared to the first two equations.

We bring the distinction between fixed-base and moving base TELs into our final estimation. Conveniently for our study, exactly three of the six states that include tuition in their TEL have a moving-based TEL while the other three have a fixed-base TEL. The results in equation (4) indicate that for states with broad-based TELs a moving-based formula has led to a greater effect than a fixed-base formula. This is what we expected. In both of the cases, broad-based TELs restrict higher education effort, but it is more severely restricted in the states with limits on the growth of state spending rather than on its level. The results for the states that do not include tuition in the TEL are puzzling. In this case moving-base TELs do not appear to affect taxpayer effort for higher education, while fixed-base TELs have the expected negative effect. In this specification the coefficient on the super majority requirement variable is no longer statistically significant.

The tax revolt clearly has had a statistically significant effect on taxpayer effort on behalf of higher education, though the magnitude of this effect varies with the type of TEL. The data behind Figure 1 indicate that nationwide taxpayer effort peaked in 1976 and 1978 at $\$ 10.56$ per $\$ 1,000$ of personal income and fell to $\$ 7.84$ in 2001 . With the 
exception of two earlier SMRs in Arkansas (1934) and Florida (1971), all of the tax revolt policies were initiated in 1976 or thereafter. Our indicator variables therefore primarily affect estimates for the period in which national average taxpayer effort fell a bit less than $\$ 3.00$ per $\$ 1,000$ of personal income. The coefficients for TEL of -.8759 and for SMR of -.4783 in Equation 1 then are quite large. The presence of a TEL accounts for slightly more than one third of the average decline while the presence of an SMR accounts for roughly one fifth of the average decline. Our other results suggest that this effect has not been uniform across states. States with very broad-based TELs have experienced much greater declines in higher education effort than have other states.

The final table, Table 7, gives the average values of the coefficients for the state indicator variables from equation 1 by region along with the F-value for the hypothesis that this average value equals zero. The omitted state was Alabama, so the coefficients for the state indicator variables measure, other things held constant, the state specific effects relative to the state of Alabama. The table indicates our results are consistent with earlier findings concerning regional effects on higher education appropriations. ${ }^{27}$ Specifically, they show that the Northeast (New England and Middle Atlantic), the Upper Midwest regions (East and West North Central) and the South Atlantic have systematically lower tax effort for higher education than Alabama while states in the remainder of the regions do not. In each case these regional averages are statistically significantly different from zero. The regional averages for the remaining regions are not statistically different from zero. The results for New England clearly are the most

\footnotetext{
${ }^{27}$ See for example, Hearn, Griswold, and Marine (1996).
} 
striking and can probably be traced to the prevalence of private colleges and universities in this region. ${ }^{28}$

We can extract two conclusions from our empirical results. First, our findings clearly indicate that the tax revolt provisions do affect higher education spending. As we discussed in Section II, previous attempts to measure the effects of tax revolt provisions have had mixed results. These other studies all focused on the total state budget while we focus on one of its components. If the studies that found a significant link between the tax revolt provisions and the total budget are correct, then our finding is that higher education spending is reduced by these provisions along with the rest of the budget. Alternatively, the tax revolt limitations may affect the composition of spending and not its level. If this is true, our results suggest that higher education spending is more vulnerable than are other spending categories. ${ }^{29}$ In any event, our results clearly suggest that the tax revolt provisions do matter. The second conclusion is a corollary to the first. Since the tax revolt provisions account for significant portion of the slowdown in taxpayer effort directed toward higher education, studies of state higher education spending should not ignore institutions such as TELs and SMRs. Also, given the importance of these institutions, strategies to improve higher education funding that ignore them may well not be useful.

\section{Policy Implications}

\footnotetext{
${ }^{28} \mathrm{We}$ did not include the prevalence of private colleges and universities as an explanatory variable because this effect is largely captured in the state indicator variable, as this regional example demonstrates.

${ }^{29}$ Even if TELs and SMRs do not reduce state spending, they may slow its growth. Higher education's share of the budget might not do well in the resulting budget crunch. Since colleges and universities have tuition as an alternative revenue source - while, for example, prisons do not - legislators may use reductions in higher education appropriations to cushion other parts of the budget.
} 
The notion that a TEL can have a very influential effect on higher education policy will not surprise anyone familiar with recent changes in higher education financing in Colorado. Starting in fall 2005, Colorado will dramatically reduce its funding for colleges and universities while instituting a voucher that goes directly to students. ${ }^{30}$ While there is a constituency for funding college and university students directly using vouchers, the fiscal environment created by Colorado's TEL probably had more to do with the passage of this reform. ${ }^{31}$ The TEL in Colorado, called the Taxpayers Bill of Rights (TABOR), is of the most restrictive type. In the language of this paper, it is a TEL that includes tuition and has a moving base. The appeal of the voucher proposal to the major universities is a legal provision allowing state entities receiving less than ten percent of their revenues from state appropriations to achieve "enterprise status." With this status they are exempted from the TABOR limitations. This exemption will allow them to use tuition increases more freely to make up for lost direct funding from the state and to meet future cost increases.

Though extreme, the Colorado case illustrates the problems public colleges and universities face in most states as the financial compact between the states and their public higher education institutions continues to erode. A good higher education system has two basic attributes: high quality and full access for qualified students regardless of means. From the end of the Second World War to roughly 1980, most states used some form of the low-tuition low-financial aid model to achieve these goals. So long as sufficient resources are flowing from the state, low tuition can guarantee access without compromising educational quality. But when resource constraints tighten, the states -

\footnotetext{
${ }^{30}$ See Alexander Russo (2004) for a discussion of the changes in Colorado.

${ }^{31}$ See Robert B. Archibald and David H. Feldman (2004) for a discussion of the reasons to support direct funding of students at state-supported colleges and universities.
} 
and their public universities - must face an unpleasant tradeoff between access and quality. Higher tuition can preserve quality, but at the cost of diminished access.

High quality and full access also can be achieved using a high-tuition highfinancial aid policy. Supporters of the high-high policy argue that the state appropriations needed to finance low tuition for all students amount to a very poorly targeted state subsidy. ${ }^{32}$ Many students attending state-supported colleges and universities are from very well-to-do families fully capable of paying much more than the current tuition. Subsidizing them improves neither quality nor access, while it increases the fiscal footprint of higher education.

While not denying this logic, proponents of the low-low strategy argue that the substantial need-based financial aid required for full access under a high tuition policy would be hard to sustain politically. Attempts to implement the high-high strategy would not yield high-high but rather high-low. This argument for a low-low strategy is based on the concept of targeting within universalism. ${ }^{33}$ Social security is an example. If social security were available only to low-income elderly, the program likely would not have very wide support, but because everyone over age 65 is eligible it has great political appeal. Advocates of social security will admit that some of the beneficiaries have no need for the money. While this may be unfortunate, the more important point is that members of the target group - the low-income elderly - are being aided. To get the government assistance to the target group, the benefit has to be embedded in a universal program. The parallels to tuition policy should be clear. Low tuition for all creates a

\footnotetext{
${ }^{32}$ This view is typically advocated by economists. For early expressions of this view see, for example, Milton Friedman (1968), W. Lee. Hansen and Burton. A. Weisbrod (1969) and the Carnegie Commission on Higher Education (1973).

${ }^{33}$ See William Julius Wilson (1987) and Theda Skocpol (1995).
} 
broad base of political support for spending on higher education, and it keeps the price down for low-income students. ${ }^{34}$

Although the political appeal of the low-low strategy seems clear, state appropriations for higher education have not kept pace with the cost of providing a high quality education. As a result, many states have allowed tuition increases that far outpace the inflation rate. These large tuition increases have received a great deal of national attention. Authority to increase tuition has not been as forthcoming in other states, and as a result the quality of the education offered by state-supported colleges and universities in these states has declined. This outcome has received much less national attention. Neither outcome is desirable. Unless states that have allowed tuition to soar also have increased their spending on financial aid accordingly, they are moving in the direction of the high-low strategy which restricts access for low-income students. If tuition is kept low but the institutions are starved, access may seem to have been preserved, but if course offerings are reduced or places in classes are rationed then access is circumscribed in other ways. And if program quality suffers, access to the resulting institution is unlikely to be as worthwhile.

Our results imply that turning the clock back to the early 1970s is a difficult enterprise. Attacking the tax and expenditure limitations or the supermajority requirements would require a pro-tax coalition that is stronger than the anti-tax forces that implemented them. But there is no evidence that support for these explicit limitations is waning. Higher education advocates are forced into the uncomfortable position of arguing that incremental budget support for higher education is more

\footnotetext{
${ }^{34}$ The arguments in the high-high vs. low-low debate are much more subtle and extensive than our brief discussion may suggest. Interested readers should see the excellent review of this literature in James C. Hearn, Carolyn P. Griswold and Ginger M. Marine (1996).
} 
important than other state services. This is a difficult case to make, given the demands of budget competitors like K-12 education, Medicaid, and highway infrastructure.

If a return to low-low is unlikely, the road to high-high has some potholes as well. First, a college president or the leader of a state-system often is hired for, and evaluated on, his or her expertise in extracting funds from the legislature. Advising that leader not to resist tuition increases and to support increased funding for need-based financial aid instead of support for his or her institution is advice to fail at state fund raising. Also, in the current environment, state need-based aid is growing much less rapidly than is state merit-based aid. Need-based aid isn't the popular option. Many states are expanding merit-based aid, and one state (Georgia) has replaced its entire needbased program with one based on merit.

Yet the case for high-high remains viable. Advocates of low-low implicitly assume that the aid needed to make high-high work must come from the state, and that this makes high-high politically unsustainable. But states are increasingly willing to let their public institutions behave more like private universities in a number of dimensions. Public universities could treat the published tuition as a list price and offer internal discounts based on need as private universities have done for years. This way, much of the aid needed to preserve access would come from internal grants. Continued state support of university operating budgets and aid funds would help keep the list price lower than it otherwise would be, but state financing would not be the single key to making high-high work. This degree of independence from the state is likely to be an attractive option for the strongest state supported institutions; those that compete effectively with 
private colleges and universities currently. ${ }^{35}$ It is not likely to be a successful strategy for community colleges or less well known state colleges and universities.

\section{Conclusions}

Our results clearly support two conclusions. First, the two tax revolt institutions tax and expenditure limits and supermajority requirements - have had a significant adverse effect on state appropriations for higher education per $\$ 1000$ of state personal income. Second, not all tax and expenditure limitations have the same effect. Broadly based limitations have much stronger effects than more narrowly based ones. We show that these provisions, which became popular starting in the late 1970s and expanded in the 1980s and 1990s, play an important role in explaining the difficulties that have plagued many state higher education systems in maintaining state appropriations during the same time period. In states with these provisions, the rules have changed to the detriment of higher education.

On their face these results might not seem surprising. If there are legal limits on taxes or expenditures, these limits likely would affect spending on higher education along with other spending. On the other hand, although TELs and SMRs are products of the tax revolt, they are not the only product. Attitudes about government and legislative behavior changed too. Strong resistance to increases in taxes or spending is a feature of many a successful legislative campaign in states that do not have a TEL or an SMR. Our results suggest that even in an environment which is very hostile to taxes and government spending, the presence of explicit limitations has a noticeable effect. The fact that a majority of these provisions are cast in constitutional concrete adds more significance to

\footnotetext{
${ }^{35}$ Three universities in Virginia are proposing to become quasi-private entities that control tuition and financial aid policy. See Pamela Burdman (2004) for a discussion.
} 
the results. It will not be easy for supporters of increases in funding for higher education to succeed in states which have these provisions. 


\section{References}

Abrams, Burton A. and William R. Dougan, "The Effects of Constitutional Restraints on Government Spending," Public Choice, 49, (1986) pp 101-116.

Archibald, Robert B. and David H. Feldman, "Direct Funding of Students at Public Colleges and Universities," NACUBO Business Officer, October 2004, pp. 27-32.

Bails, Dale and Martie A. Tieslau, "The Impact of Fiscal Constitutions on State and Local Expenditures," Cato Journal, 20, pp. 255-227.

Berry, William D., Evan J. Ringquist, Richard C. Fording, and Russel L. Hanson, "Measuring Citizen and Government Ideology in the American States," American Journal of Political Science, 42 (1998) pp. 327-348.

Besley, Thomas and Anne Case, "Political Institutions and Policy Choices, Evidence from the United States," Journal of Economic Literature, XLI (2003) pp. 7-73.

Black, Earl and Merle Black, The Rise of Southern Republicans, (Harvard University Press, 2002).

Bound, John, David A. Jaeger, and Regina Baker, "Problems with Instrumental Variables Estimation When the Correlation between the Instruments and the Endogenous Explanatory Variable is Weak," Journal of the American Statistical Association, 90 (430) June 1995, pp. 443-450.

Burdman, Pamela, "Has the State Become an Albatross? Some of Virginia's public universities and seeking greater freedom to set tuition," National CrossTalk, 12, (2004).

Carnegie Commission on Higher Education, Higher Education: Who Pays? Who Benefits? Who Should Pay (McGraw Hill, 1973).

Downs, Anthony, An Economic Theory of Democracy. New York: Harper Collins, 1957.

Ehrenberg, Ronald G., Tuition Rising: Why College Costs So Much (Harvard University Press, 2000).

Friedman, Milton, “The Higher Schooling in America,” Public Interest, 11, (1968) pp. 108-112.

Gilligan, Thomas W., and John G. Matsusaka, "Deviation from Constituent Interests: The Role of Legislative Structure and Political Parties in the States," Economic Inquiry, 33 (July 1995), pp. 383-401. 
Griswold, Carolyn P. and Ginger Minton Marine, "Political Influences on State Policy: Higher-Tuition, Higher-Aid, and the Real World," The Review of Higher Education, 19 (1996) pp. 361-389.

Hansen, W. Lee and Burton A Weisbrod, Benefits, Costs, and Finance of Public Higher Education (Markham Publishing, 1973).

Hauptman, Arthur M. The College Tuition Spiral: An Examination of Why Charges Are Increasing (American Council of Education and the College Board, 1990).

Hearn, James C., Carolyn P. Griswold, and Ginger M. Marine, "Region, Resources, and Reason: A Contextual Analysis of State Tuition and Student Aid Policies," Research in Higher Education, 37, (1996), pp. 241-278.

Hossler, Don, Jon P. Lund, Jackie Ramin, Sara Westfall, and Steve Irish, "State Funding for Higher Education: The Sisyphean Task, The Journal of Higher Educaiton, 8, (1997) pp. 160-190.

Kane, Thomas J., Peter R. Orszag, and David L. Gunter, "State Fiscal Constraints and Higher Education Spending: The Role of Medicaid and the Business Cycle," Discussion Paper No. 11, The Brookings Institution, May 2003.

Knight, Brian G., "Supermajority Voting Requirements for Tax Increases: Evidence from the States," Journal of Public Economics, 76, (2000) pp. 41-67.

Koshal, Rajindar K., and Manjulika Koshal, "State Appropriations and Higher Education Tuition: what is the relationship?" Education Economics, 8, (2000), pp. 81-89.

Lamis, Alexander, The Two-party South, (Oxford University Press, 1984).

Lowry, Robert C., "The effects of state political interests and campus outputs on public university revenues," Economics of Education Review, 20, (2001) pp. 105-119.

Matsusaka, John, "Fiscal Effects of the Voter Initiative: Evidence from the Last 30 Years.” Journal of Political Economy, 103 (June 1995), pp. 587-623.

Romer, Thomas, and Howard Rosenthal, "Political Resource Allocation, Controlled Agendas, and the Status Quo," Public Choice, 33, (\#4 1978), pp. 27-43.

Rueben, Kim, "Tax Limitations and Government Growth: The Effect of State Tax and Expenditure Limits on State and Local Government," California Institute of Public Policy, 1997.

Russo, Alexander, "Varsity Vouchers: Colorado has come up with a novel way to fund higher education. Send money to the students." State Legislatures, (June 2004), page 27. 
Shadbegian, Ronald J., "Do Tax and Expenditure Limitations Affect the Size and Growth of State Government?” Contemporary Economic Policy, 14, (1996) pp 22-36.

Shepsle, Kenneth A., and Barry R. Weingast, "Structure-Induced Equilibrium and Legislative Choice,” Public Choice, 37, (\#3 1981), pp. 503-19.

Skocpol, Theda, "Targeting Within Universalism, Politically Viable Policies to Combat Poverty in the United States," chapter 8 of Social Policy in the United States: Future Possibilities in Historical Perspective. Princeton: Princeton University Press, 1995.

Tabellini, Guido, and Alberto Alesina, "Voting on the Budget Deficit," American Economic Review, 80, (1990), pp. 37-49.

Wilson, William Julius, The Truly Disadvantaged: The Inner City, the Underclass, and Public Policy. Chicago: University of Chicago Press, 1987. 
Table 1. Tax and Expenditure Limitations

\begin{tabular}{|l|l|l|l|l|l|}
\hline State & $\begin{array}{l}\text { Date } \\
\text { Initiated }\end{array}$ & $\begin{array}{l}\text { Const. or } \\
\text { Statutory }\end{array}$ & $\begin{array}{l}\text { Limit Restrictive or } \\
\text { Non-Restrictive }\end{array}$ & $\begin{array}{l}\text { Fixed or } \\
\text { Moving Base }\end{array}$ & $\begin{array}{l}\text { Tuition } \\
\text { Included? }\end{array}$ \\
\hline AK & 1982 & Const. & Restrictive & Fixed & No \\
\hline AZ & 1978 & Const. & Restrictive & Fixed & Yes \\
\hline CA & 1979 & Const. & Restrictive & Fixed & No \\
\hline CO & 1977 & $\begin{array}{l}\text { Stat }-1991 \\
\text { Const }-1992\end{array}$ & Non-Restrictive & Moving & Yes \\
\hline CT & 1991 & Const. & Non-Restrictive & Moving & No \\
\hline FL & 1994 & Const. & Non-Restrictive & Moving & No \\
\hline HI & 1978 & Const. & Restrictive & Moving & No \\
\hline ID & 1978 & Stat. & Restrictive & Fixed & No \\
\hline LA & 1979 & $\begin{array}{l}\text { Stat-1979 } \\
\text { Const- } 1993\end{array}$ & Non-Restrictive & Fixed & No \\
\hline MA & 1986 & Stat. & Restrictive & Moving & No \\
\hline MI & 1978 & Const. & Restrictive & Fixed & No \\
\hline MO & 1980 & Const. & Restrictive & Fixed & No \\
\hline MT & 1981 & Stat. & Restrictive & Moving & No \\
\hline NC & 1991 & Stat. & Non-Restrictive & Fixed & Yes \\
\hline NJ & 1976 & Stat. & Restrictive & Moving & No \\
\hline NV & 1979 & Stat. & $\begin{array}{l}\text { Non-Restrictive -1981 } \\
\text { Restrictive - 1995 }\end{array}$ & Fixed & Yes \\
\hline OK & 1985 & Const. & Restrictive & Moving & No \\
\hline OR & 1979 & Stat. & Non-Restrictive & Moving & Yes \\
\hline SC & 1980 & Const. & Restrictive & Moving & No \\
\hline TN & 1978 & Const. & Non-Restrictive & Moving & No \\
\hline TX & 1978 & Const. & Non-Restrictive & Moving & No \\
\hline UT & 1979 & Stat. & Non-Restrictive & $\begin{array}{l}\text { Mix of Fixed } \\
\text { and Moving }\end{array}$ & No \\
\hline WA & 1979 & Stat. & Restrictive & Moving & Yes \\
\hline
\end{tabular}


Table 2. Characteristics of Super Majority Requirements

\begin{tabular}{|l|l|l|}
\hline State & Year & Voting Requirements \\
\hline AR & 1934 & $3 / 4$ or voter approval \\
\hline AZ & 1992 & $2 / 3$ \\
\hline CA & 1978 & $2 / 3$ \\
\hline CO & 1992 & $2 / 3$ temporary and then voter approval \\
\hline DE & 1980 & $3 / 5$ \\
\hline FL & 1971 & $3 / 5$ \\
\hline LA & 1996 & $2 / 3$ \\
\hline MS & 1970 & $3 / 5$ \\
\hline NV & 1996 & $2 / 3$ emergency and then voter approval \\
\hline OK & 1996 & $3 / 4$ or voter approval \\
\hline OR & 1996 & $3 / 5$ \\
\hline SD & 1978 & $2 / 3$ \\
\hline WA & 1993 & $\begin{array}{l}2 / 3 \text { for revenue increases under the expenditure limit } \\
\text { otherwise voter approval }\end{array}$ \\
\hline
\end{tabular}


Table 3. Years of Peak Effort by State

\begin{tabular}{|l|l|l|l|l|l|l|}
\hline Years & States & & & \\
\hline $\mathbf{1 9 6 6}$ & SD & & & & & \\
\hline $\mathbf{1 9 6 7}$ & & & & & & \\
\hline $\mathbf{1 9 6 8}$ & & & & & & \\
\hline $\mathbf{1 9 6 9}$ & & & & & & \\
\hline $\mathbf{1 9 7 0}$ & VT & & & & & \\
\hline $\mathbf{1 9 7 1}$ & CO & HI & IL & MT & OR & \\
\hline $\mathbf{1 9 7 2}$ & IN & LA & & & & \\
\hline $\mathbf{1 9 7 3}$ & & & & & & \\
\hline $\mathbf{1 9 7 4}$ & AZ & GA & ME & WA & WI & \\
\hline $\mathbf{1 9 7 5}$ & FL & PA & SC & & & \\
\hline $\mathbf{1 9 7 6}$ & DE & MD & MI & NH & NY & WV \\
\hline $\mathbf{1 9 7 7}$ & ID & MO & NV & & & \\
\hline $\mathbf{1 9 7 8}$ & CT & MN & NE & NJ & UT & \\
\hline $\mathbf{1 9 7 9}$ & KS & KY & MS & RI & TN & VA \\
\hline $\mathbf{1 9 8 0}$ & CA & & & & & \\
\hline $\mathbf{1 9 8 1}$ & & & & & & \\
\hline $\mathbf{1 9 8 2}$ & AK & NC & ND & TX & & \\
\hline $\mathbf{1 9 8 3}$ & OK & & & & & \\
\hline $\mathbf{1 9 8 4}$ & & & & & & \\
\hline $\mathbf{1 9 8 5}$ & NM & & & & & \\
\hline $\mathbf{1 9 8 6}$ & AL & AR & & & & \\
\hline $\mathbf{1 9 8 7}$ & & & & & & \\
\hline $\mathbf{1 9 8 8}$ & MA & & & & & \\
\hline $\mathbf{1 9 8 9}$ & OH & WY & & & & \\
\hline $\mathbf{1 9 9 0}$ & & & & & & \\
\hline $\mathbf{1 9 9 1}$ & IA & & & & & \\
\hline
\end{tabular}


Table 4. State Appropriations for Higher Education per \$1,000 of Personal Income in Rank Order, FY 1961, 1970, 1980, 1990, and 2000

\begin{tabular}{|c|c|c|c|c|c|c|c|c|c|c|}
\hline \multicolumn{3}{|c|}{1961} & \multicolumn{2}{|c|}{1970} & \multicolumn{2}{|c|}{1980} & \multicolumn{2}{|c|}{1990} & \multicolumn{2}{|c|}{2000} \\
\hline Rank & State & Effort & State & Effort & State & Effort & State & Effort & State & Effort \\
\hline 1 & MA & $\$ .98$ & MA & $\$ 3.89$ & $\mathrm{NH}$ & $\$ 4.28$ & $\mathrm{NH}$ & $\$ 3.23$ & $\mathrm{NH}$ & $\$ 2.72$ \\
\hline 2 & NJ & 1.35 & $\mathrm{NJ}$ & 4.25 & MA & 6.47 & MA & 6.45 & VT & 4.30 \\
\hline 3 & MD & 1.54 & $\mathrm{NH}$ & 4.38 & NJ & 7.44 & VT & 6.47 & MA & 5.07 \\
\hline 4 & NY & 1.64 & CT & 6.09 & $\mathrm{OH}$ & 7.53 & CT & 6.51 & NY & 5.44 \\
\hline 5 & CT & $\begin{array}{l}1.78 \\
\end{array}$ & MD & 6.30 & CT & 7.53 & NJ & 6.58 & RI & 5.50 \\
\hline 6 & PA & 1.80 & $\mathrm{OH}$ & 6.31 & PA & 7.61 & PA & 6.66 & NJ & 5.53 \\
\hline 7 & $\mathrm{OH}$ & 2.04 & PA & 7.71 & $\mathrm{ME}$ & 7.62 & RI & 7.04 & $\mathrm{CT}$ & 5.57 \\
\hline 8 & MO & 2.73 & NV & 7.74 & VT & 7.72 & $\mathrm{MO}$ & 7.13 & PA & 5.67 \\
\hline 9 & ME & 3.08 & $\overline{D E}$ & 7.77 & NV & 8.09 & FL & 7.19 & NV & 5.88 \\
\hline 10 & $\mathrm{TN}$ & 3.11 & VA & 7.93 & MO & 8.30 & NV & 7.50 & $\mathrm{CO}$ & 6.07 \\
\hline 11 & VA & 3.11 & NY & 8.07 & MD & 8.71 & $\mathrm{OH}$ & 7.89 & FL & 6.52 \\
\hline 12 & $\mathrm{DE}$ & 3.12 & OK & 8.07 & IL & 8.78 & IL & 8.09 & MD & 6.59 \\
\hline 13 & $\mathrm{NH}$ & 3.13 & $\mathrm{TN}$ & 8.20 & WA & 8.98 & MD & 8.56 & $\mathrm{MO}$ & 7.03 \\
\hline 14 & RI & 3.16 & $\mathrm{MO}$ & 8.28 & FL & 8.99 & NY & 8.62 & $\mathrm{OH}$ & 7.04 \\
\hline 15 & IL & 3.34 & $\mathrm{AL}$ & 8.36 & IN & 9.27 & GA & 8.82 & IL & 7.11 \\
\hline 16 & TX & 3.54 & RI & 8.73 & NY & 9.70 & MI & 8.87 & ME & 7.23 \\
\hline 17 & $\mathrm{SC}$ & 3.67 & IN & 8.91 & RI & 9.74 & SD & 8.90 & MT & 7.31 \\
\hline 18 & FL & 3.86 & MI & 8.99 & MI & 9.94 & $\mathrm{CO}$ & 8.97 & $\mathrm{TN}$ & 7.34 \\
\hline 19 & KY & 4.09 & ME & 9.10 & MT & 9.99 & OR & 8.99 & SD & 7.45 \\
\hline 20 & $\mathrm{AK}$ & 4.12 & $\mathrm{IL}$ & 9.11 & $\overline{D E}$ & 10.29 & ME & 9.12 & WA & 7.58 \\
\hline 21 & GA & 4.14 & CA & 9.18 & SD & 10.32 & $\mathrm{DE}$ & 9.24 & $\mathrm{AZ}$ & 7.67 \\
\hline 22 & $\mathrm{NC}$ & 4.25 & $\mathrm{NE}$ & 9.19 & GA & 10.42 & LA & 9.37 & VA & $\begin{array}{l}7.68 \\
\end{array}$ \\
\hline 23 & WI & 4.32 & FL & 9.50 & $\mathrm{CO}$ & 10.45 & IN & 9.50 & OR & 7.72 \\
\hline 24 & $\mathrm{CA}$ & 4.40 & GA & 9.59 & VA & 10.45 & VA & 9.72 & GA & 7.76 \\
\hline 25 & $\mathrm{AL}$ & 4.49 & $\mathrm{AK}$ & 9.79 & OK & 10.63 & $\mathrm{TN}$ & 9.86 & WI & 7.80 \\
\hline 26 & VT & 4.71 & MS & 9.80 & OR & 10.77 & $\mathrm{AZ}$ & 9.93 & MI & 7.88 \\
\hline 27 & IN & 4.86 & SD & 9.83 & $\mathrm{TN}$ & 10.91 & CA & 9.94 & TX & 7.95 \\
\hline 28 & MN & 5.30 & MN & 10.00 & IA & 11.45 & OK & 10.03 & $\overline{\mathrm{DE}}$ & 8.03 \\
\hline 29 & MI & 5.35 & LA & 10.03 & $\mathrm{AR}$ & 11.63 & WI & 10.18 & IN & 8.22 \\
\hline 30 & $\mathrm{NV}$ & 5.35 & VT & 10.06 & LA & 11.66 & MT & 10.23 & CA & 8.27 \\
\hline 31 & $\mathrm{NE}$ & 5.39 & TX & 10.12 & ND & 11.68 & TX & 10.28 & LA & 9.06 \\
\hline 32 & $\mathrm{HI}$ & 5.64 & $\mathrm{AR}$ & 10.40 & $\mathrm{NE}$ & 11.91 & WA & 10.40 & MN & 9.19 \\
\hline 33 & WV & 5.71 & $\mathrm{SC}$ & 10.70 & $\mathrm{AZ}$ & 12.18 & $\mathrm{AR}$ & 10.51 & $\mathrm{SC}$ & 9.38 \\
\hline 34 & $\mathrm{CO}$ & 6.02 & IA & 10.94 & WI & 12.20 & KS & 10.83 & KS & 9.57 \\
\hline 35 & UT & 6.05 & $\mathrm{KY}$ & 10.99 & KY & 12.24 & WV & 10.94 & WV & 9.87 \\
\hline 36 & MS & 6.09 & KS & 11.01 & WV & 12.28 & KY & 11.02 & $\mathrm{OK}$ & 9.92 \\
\hline 37 & KS & 6.14 & WI & 11.09 & TX & 12.32 & $\mathrm{NE}$ & 11.67 & $\mathrm{AK}$ & 10.30 \\
\hline 38 & WA & 6.26 & MT & 11.72 & $\mathrm{KS}$ & 12.67 & ID & 11.85 & ID & 10.32 \\
\hline 39 & OK & 6.35 & WV & 12.13 & ID & 12.75 & IA & 12.46 & KY & 10.50 \\
\hline 40 & $\mathrm{AZ}$ & 6.36 & $\mathrm{CO}$ & 12.15 & WY & 12.78 & MN & 12.53 & $\mathrm{HI}$ & 10.74 \\
\hline 41 & NM & 6.41 & $\mathrm{AZ}$ & 12.62 & CA & 12.81 & $\mathrm{SC}$ & 12.78 & UT & 10.93 \\
\hline 42 & WY & 6.46 & OR & 12.69 & $\mathrm{AL}$ & 13.83 & UT & 13.17 & $\mathrm{NE}$ & 10.97 \\
\hline 43 & AR & 6.54 & $\mathrm{NC}$ & 12.77 & MN & 14.08 & $\mathrm{HI}$ & 13.69 & AR & 11.25 \\
\hline 44 & IA & 6.62 & $\begin{array}{l}\text { UT } \\
\end{array}$ & 13.40 & $\begin{array}{l}\text { UT } \\
\end{array}$ & 14.45 & $\mathrm{AL}$ & 13.94 & $\mathrm{AL}$ & 11.40 \\
\hline 45 & OR & 7.09 & NM & 13.42 & $\mathrm{HI}$ & 14.64 & MS & 14.37 & WY & 11.52 \\
\hline 46 & SD & 7.81 & WY & 13.66 & $\mathrm{NC}$ & 14.91 & $\mathrm{NC}$ & 14.56 & IA & 11.56 \\
\hline 47 & ID & 8.46 & ND & 13.77 & NM & 16.17 & NM & 14.93 & $\mathrm{NC}$ & 11.79 \\
\hline 48 & LA & 8.76 & $\mathrm{HI}$ & 14.16 & MS & 16.18 & ND & 15.51 & ND & 12.48 \\
\hline 49 & ND & 8.91 & ID & 14.76 & $\mathrm{SC}$ & 16.63 & AK & 16.54 & NM & 14.76 \\
\hline 50 & MT & 9.61 & WA & 15.16 & $\mathrm{AK}$ & 19.13 & WY & 16.69 & MS & 15.94 \\
\hline
\end{tabular}


Table 5. List of Variables

\begin{tabular}{|c|c|c|c|}
\hline Variables & Mean & $\begin{array}{l}\text { Standard } \\
\text { Deviation }\end{array}$ & Source \\
\hline $\begin{array}{l}\text { Higher Education } \\
\text { Appropriations per } \\
\$ 1,000 \text { of State } \\
\text { Personal Income }\end{array}$ & $\$ 9.08$ & 3.11 & $\begin{array}{l}\text { Grapevine Project } \\
\text { www.coe.ilstu.edu/grapevine/ }\end{array}$ \\
\hline TEL & .2158 & .4114 & Www.limitedgovernment.org \\
\hline SMR & .1301 & .3365 & Www.limitedgovernment.org \\
\hline $\begin{array}{l}\text { Corrections } \\
\text { spending per } \$ 1,000 \\
\text { of State Personal } \\
\text { Income }\end{array}$ & $\$ 2.41$ & 1.20 & $\begin{array}{l}\text { Census Bureau and } \\
\text { Bureau of Economic Analysis }\end{array}$ \\
\hline $\begin{array}{l}\text { Health and } \\
\text { Hospitals spending } \\
\text { per } \$ 1,000 \text { of State } \\
\text { Personal Income }\end{array}$ & $\$ 7.63$ & 2.79 & $\begin{array}{l}\text { Census Bureau and } \\
\text { Bureau of Economic Analysis }\end{array}$ \\
\hline Ideology & 46.14 & 16.34 & $\begin{array}{l}\text { Berry, Ringquist, Fording and Hanson } \\
\text { (1998) and } \\
\text { www.icpsr.umich.edu:8080/ICPSR- } \\
\text { STUDY/01208.xml }\end{array}$ \\
\hline $\begin{array}{l}\text { Democratic } \\
\text { Governor }\end{array}$ & .5596 & .4966 & Book of States \\
\hline $\begin{array}{l}\text { Democratic } \\
\text { Majority Lower } \\
\text { House }\end{array}$ & .6484 & .4776 & Book of the States \\
\hline $\begin{array}{l}\text { Democratic } \\
\text { Majority Upper } \\
\text { House }\end{array}$ & 6249 & .4843 & Book of the States \\
\hline $\begin{array}{l}\text { Population } \\
\text { Percentage 18-24 }\end{array}$ & 11.28 & 1.75 & Census Bureau \\
\hline $\begin{array}{l}\text { Population } \\
\text { Percentage } 5-17\end{array}$ & 22.15 & 3.56 & Census Bureau \\
\hline $\begin{array}{l}\text { Population } \\
\text { Percentage }>65\end{array}$ & 11.16 & 2.21 & Census Bureau \\
\hline State Population & $4,760,232$ & $4,975,360$ & Statistical Abstract of the United States \\
\hline
\end{tabular}


Table 6. Regression Results for Tax Revolt, Other State Spending, and Political Variables

\begin{tabular}{|c|c|c|c|c|c|}
\hline & Independent Variable & $\mathbf{1}$ & 2 & 3 & 4 \\
\hline \multirow{10}{*}{$\begin{array}{l}\text { Tax } \\
\text { Revolt } \\
\text { Variables }\end{array}$} & TEL & $\begin{array}{l}-.8759 \\
(7.84)\end{array}$ & & & \\
\hline & Restrictive TEL & & $\begin{array}{l}-.7986 \\
(5.78)\end{array}$ & & \\
\hline & Non-Restrictive TEL & & $\begin{array}{l}-.9812 \\
(6.99) \\
\end{array}$ & & \\
\hline & TEL Includes Tuition & & & $\begin{array}{l}-2.1066 \\
(13.14)\end{array}$ & \\
\hline & TEL Excludes Tuition & & & $\begin{array}{l}-.3737 \\
(2.91) \\
\end{array}$ & \\
\hline & $\begin{array}{l}\text { TEL Includes Tuition, } \\
\text { Moving Base }\end{array}$ & & & & $\begin{array}{r}-2.7932 \\
(15.84)\end{array}$ \\
\hline & $\begin{array}{l}\text { TEL Includes Tuition, } \\
\text { Fixed Base }\end{array}$ & & & & $\begin{array}{c}-1.3316 \\
(5.79) \\
\end{array}$ \\
\hline & $\begin{array}{l}\text { TEL Excludes } \\
\text { Tuition, Moving Base }\end{array}$ & & & & $\begin{array}{l}.0906 \\
(0.59) \\
\end{array}$ \\
\hline & $\begin{array}{l}\text { TEL Excludes } \\
\text { Tuition, Fixed Base } \\
\end{array}$ & & & & $\begin{array}{r}-1.2067 \\
(6.66) \\
\end{array}$ \\
\hline & SMR & $\begin{array}{l}-.4783 \\
(2.75)\end{array}$ & $\begin{array}{l}-. .4960 \\
(2.84)\end{array}$ & $\begin{array}{l}-.3501 \\
(2.03)\end{array}$ & $\begin{aligned}-.2018 \\
(1.24)\end{aligned}$ \\
\hline \multirow{2}{*}{$\begin{array}{l}\text { Other } \\
\text { State } \\
\text { Spending }\end{array}$} & Corrections & $\begin{array}{l}.1477 \\
(3.20)\end{array}$ & $\begin{array}{l}.1482 \\
(3.21)\end{array}$ & $\begin{array}{l}.1143 \\
(2.61)\end{array}$ & $\begin{array}{l}.0965 \\
(2.20)\end{array}$ \\
\hline & Health and Hospitals & $\begin{array}{l}.2159 \\
(11.81)\end{array}$ & $\begin{array}{l}.2157 \\
(11.79)\end{array}$ & $\begin{array}{l}.1965 \\
(10.85)\end{array}$ & $\begin{array}{l}.1990 \\
(11.16)\end{array}$ \\
\hline \multirow[t]{8}{*}{$\begin{array}{l}\text { Political } \\
\text { Controls }\end{array}$} & Ideology & $\begin{array}{l}.0123 \\
(2.87) \\
\end{array}$ & $\begin{array}{l}.0125 \\
(2.90) \\
\end{array}$ & $\begin{array}{l}.0133 \\
(3.17) \\
\end{array}$ & $\begin{array}{l}.0114 \\
(2.76) \\
\end{array}$ \\
\hline & Democratic Governor & $\begin{array}{l}-.3598 \\
(4.25)\end{array}$ & $\begin{array}{l}-.3652 \\
(4.30)\end{array}$ & $\begin{array}{l}-.2685 \\
(3.20)\end{array}$ & $\begin{array}{l}-.2332 \\
(2.73)\end{array}$ \\
\hline & $\begin{array}{l}\text { Democratic Governor } \\
1980 \text { and after }\end{array}$ & $\begin{array}{l}.4742 \\
(4.29) \\
\end{array}$ & $\begin{array}{l}.4810 \\
(4.36) \\
\end{array}$ & $\begin{array}{l}.4759 \\
(4.42) \\
\end{array}$ & $\begin{array}{l}.4759 \\
(4.46) \\
\end{array}$ \\
\hline & $\begin{array}{l}\text { Democratic Lower } \\
\text { House }\end{array}$ & $\begin{array}{l}-.5120 \\
(4.13)\end{array}$ & $\begin{array}{l}-.5105 \\
(4.11)\end{array}$ & $\begin{array}{l}-.4786 \\
(4.05)\end{array}$ & $\begin{array}{l}-.5146 \\
(4.43)\end{array}$ \\
\hline & $\begin{array}{l}\text { Democratic Lower } \\
\text { House } 1980 \text { and after }\end{array}$ & $\begin{array}{l}.6996 \\
(4.68) \\
\end{array}$ & $\begin{array}{l}.6976 \\
(4.66) \\
\end{array}$ & $\begin{array}{l}.5770 \\
(3.99) \\
\end{array}$ & $\begin{array}{l}.6157 \\
(4.30) \\
\end{array}$ \\
\hline & $\begin{array}{l}\text { Democratic Upper } \\
\text { House }\end{array}$ & $\begin{array}{l}.3041 \\
(2.44)\end{array}$ & $\begin{array}{l}.3023 \\
(2.43) \\
\end{array}$ & $\begin{array}{l}.2523 \\
(2.12) \\
\end{array}$ & $\begin{array}{l}.2644 \\
(2.210\end{array}$ \\
\hline & $\begin{array}{l}\text { Democratic Upper } \\
\text { House } 1980 \text { and after }\end{array}$ & $\begin{array}{l}-.2080 \\
(1.50) \\
\end{array}$ & $\begin{array}{l}-.2045 \\
(1.47) \\
\end{array}$ & $\begin{array}{l}-.2085 \\
(1.58) \\
\end{array}$ & $\begin{array}{l}-.2359 \\
(1.80)\end{array}$ \\
\hline & $\mathbf{R}^{2}$ & .8801 & .8802 & .8857 & .8895 \\
\hline
\end{tabular}


Table 7. State Effects Averaged by Region

\begin{tabular}{|l|l|c|c|}
\hline Region & States & $\begin{array}{l}\text { Average } \\
\text { Coefficient }\end{array}$ & F-Value \\
\hline New England & ME NH VT MA RI CT & -6.1302 & 282.96 \\
\hline Middle Atlantic & NY NJ PA & -2.7918 & 34.39 \\
\hline East North Central & OH IN IL MI WI & -1.1760 & 11.68 \\
\hline West North Central & MN IA MO ND SD KS & -1.1203 & 12.11 \\
\hline South Atlantic & DE MD VA WV NC SC GA FL & -1.3973 & 25.01 \\
\hline East South Central & KY TN AL MS & 0.0246 & 0.01 \\
\hline West South Central & AR LA OK TX & -0.2171 & 0.54 \\
\hline Mountain & MT ID WY CO NM AZ UT NV & 0.2885 & 0.58 \\
\hline Pacific & WA OR CA & 0.2776 & 0.63 \\
\hline
\end{tabular}

